\title{
Comparative Study on Heavy Metals Biosorption by Different Types of Bacteria
}

\author{
Eteri Gelagutashvili \\ Andronikashvili Institute of Physics, Ivane Javakhishvili Tbilisi State University, Tbilisi, Georgia \\ Email: eterige@gmail.com,gelaguta@yahoo.com
}

Received April 29, 2013; revised June 2, 2013; accepted June 12, 2013

Copyright (C) 2013 Eteri Gelagutashvili. This is an open access article distributed under the Creative Commons Attribution License, which permits unrestricted use, distribution, and reproduction in any medium, provided the original work is properly cited.

\begin{abstract}
Biosorption of $\mathrm{Cd}(\mathrm{II}), \mathrm{Ag}(\mathrm{I})$ and $\mathrm{Au}(\mathrm{III})$ by cyanobacteria Spirulina platensis, of $\mathrm{Au}(\mathrm{II})$ - by Streptomyces spp. 19H, and of $\mathrm{Cr}(\mathrm{VI})$ and $\mathrm{Cr}(\mathrm{III})$ - by Arthrobacter species was studied by using the dialysis and atomic absorption analysis under various conditions. In particular, the impact of the following parameters on biosorption was studied: $\mathrm{pH}$ (for Ag, $\mathrm{Cd}, \mathrm{Au}$ ), living and non-living cells (for $\mathrm{Cr}$ ), heavy metal valence (for $\mathrm{Cr}$ ), homogenized and non-homogenized cells (for $\mathrm{Au}$ ), $\mathrm{Zn}(\mathrm{II})$ ions (on $\mathrm{Cr}(\mathrm{VI})$-Arthrobacter species). It was shown that biosorption efficiency of $\mathrm{Cr}(\mathrm{III}), \mathrm{Cr}(\mathrm{VI})$, $\mathrm{Cd}(\mathrm{II}), \mathrm{Au}(\mathrm{III})$ and $\mathrm{Ag}(\mathrm{I})$ ions is likely to depend on the type of bacteria used as well as on the conditions under which the uptake processes proceeded. It was shown that metal removal by microorganisms was influenced by physicalchemical parameters. The $\mathrm{pH}$ value of 7.0 was optimum for the removal of $\mathrm{Ag}(\mathrm{I})$ and $\mathrm{Cd}(\mathrm{II})$ by Spirulina platensis. At a low $\mathrm{pH}$ value of 5.5, $\mathrm{Au}$ (III) was by test algae more efficiently than $\mathrm{Cd}(\mathrm{II})$ and $\mathrm{Ag}(\mathrm{I})$.
\end{abstract}

Keywords: Biosorption; Heavy Metals; Cyanobacteria; Actinomycetes

\section{Introduction}

Biosorption can be defined as the removal of metals from the solution by biological material.

The biosorbents can be bacteria, microalgae etc. Heavy metal pollution represents an important environmental problem because of toxic effects of metals. Interest in the development of metal removal by biosorption using microorganisms is shown in literature [1-11]. Cyanobacteria (blue green algae) represent the largest and most diverse group of photosynthetic prokaryotes. They are excellent organisms to serve as a model for the investigation of a wide variety of biological problems, including the indicators of environmental pollution. Spirulina platensis is a cyanobacterial species that can potentiate the immune system, leading to suppression of cancer development and viral infection [1]. The cyano-bacteria Spirulina platensis has recently been reported to accumulate multiple metals and to be a hyperaccumulator of $\mathrm{Cd}$ and $\mathrm{Pb}$ [2]. The interest in $\mathrm{Cr}$ is governed by the fact that its toxicity depends critically on its oxidation state. While $\mathrm{Cr}$ (III) is considered essential for lipid and protein metabolism, $\mathrm{Cr}(\mathrm{VI})$ is known to be toxic to humans [7]. Gram-positive Arthrobacter bacteria can reduce $\mathrm{Cr}(\mathrm{VI})$ to $\mathrm{Cr}(\mathrm{III})$ under aerobic growth, and there is great interest in $\mathrm{Cr}$ reducing bacteria. Silver nitrate was tested for antimicro- bial activity in vitro. The bactericidal action of silver with its broad spectrum of activity including bacterial, fungal and viral agents is well known [8]. Silver ions block the respiratory chain of microorganisms. Some bacteria have evolved the mechanisms of detoxication of heavy metals, and some even use them for respiration. In [9] the recovery of gold using algae cells was investigated, and in $[10,11]$ the microorganism-gold interaction was studied. The investigation of the efficacy of the metal uptake by the microbial biomass is essential for the industrial application of biosorption.

In spite of the fact that recently the interest in studying the biosorption of metals by microorganisms has increased, the exact mechanism by which microorganisms take up the metal is still relatively unclear.

The objective of this paper is to study the influence of different conditions on the biosorption of heavy metals $\mathrm{Cd}, \mathrm{Ag}, \mathrm{Cr}, \mathrm{Au}$ by actinomycetes: (Streptomyces spp. 19H), Actinomycetes belonging to Arthrobacter genera (Arthrobacter oxidas and Arthrobacter globiformis), and microalgae (Spirulina platensis).

\section{Materials and Methods}

Analytical grade reagents were used in all experiments: $\mathrm{K}_{2} \mathrm{CrO}_{4}, \mathrm{CrCl}_{3}, \mathrm{ZnSO}_{4}, \mathrm{CdSO}_{4}, \mathrm{AgNO}_{3}, \mathrm{HAuCl}_{4}$. Actin- 
omycetes belonging to Arthrobacter genera-Arthrobacter globiformis 151B and Arthrobacter oxydans 61B (isolated from the basalt rocks collected in the Kazreti region of Georgia), blue-green algae Spirulina platensis (strain IPPAS B-256) and actinomycetes Streptomyces spp. 19H (isolated from the rhizosphere of soybeans grown in Georgia) were used [12-14].

Arthrobacter bacteria were cultivated in the nutrient medium without co-cations and loaded with $\mathrm{Zn}(50 \mathrm{mg} / \mathrm{l})$ (in the case of $\mathrm{Cr}(\mathrm{VI})$ ) [12]. The cells were centrifuged at $12,000 \mathrm{rpm}$ for $10 \mathrm{~min}$ and washed three times with phosphate buffer ( $\mathrm{pH} 7.1$ ). The centrifuged cells were dried without a supernatant solution until constant weight. After solidification (dehydration) of cells (dry weight), the solutions for dialysis were prepared by dissolving in phosphate buffer. This buffer was used in all experiments.

Spirulina platensis IPPAS B-256 strain from Timiriazev Institute of Plant Physiology of the Russian Academy of Sciences was cultivated in a standard Zaroukh alkaline water-salt medium at $34^{\circ} \mathrm{C}$, illumination $\sim 5000$ lux, initial $\mathrm{pH} 8.7$ and at constant mixing [13].

To study the biosorption process on the bacterial cells, the methods of dialysis and atomic absorption analysis were used. A known quantity of dried bacteria suspension was contacted with the solution containing a known concentration of metal ions. The experiments of dialysis were carried out in 5-ml cylindrical vessels made of organic glass. A cellophane membrane $30 \mu \mathrm{m}$ wide (typeVisking, manufacturer-Serva) was used as a partition. The duration of dialysis was 72 hours. The metal concentration after the dialysis was measured by using the atomic absorption spectrophotometer Analyst-900 at the wavelength of $\lambda=328.1 \mathrm{~nm}(\mathrm{Ag}), \lambda=242.8$ (Au) $\mathrm{nm}, \lambda$ $=357.9 \mathrm{~nm}(\mathrm{Cr}) . \lambda=228 \mathrm{~nm}(\mathrm{Cd})$. For biosorption isotherm studies, the dry cell weight was kept constant (1 $\mathrm{mg} / \mathrm{ml}$ ), while the initial metal concentration in each sample was varied in the interval $10^{-3}-10^{-6} \mathrm{M}$. All experiments were carried out at ambient temperature.

Data Analysis. The isotherm data were characterized by the Freundlich equation [15]. $C_{b}=K C_{t}^{1 / n}$, where $C_{b}$ is the metal concentration adsorbed on either live or dried cells of bacteria in $\mathrm{mgg}^{-1}$ dry weight, $C_{t}$ is the equilibrium concentration of metal $\left(\mathrm{mg} \cdot \mathrm{l}^{-1}\right)$ in the solution, $K$ is the empirical constant that provides an indication $\log C_{b}$ as a function of $\log C_{t}$ of the adsorption capacity of either live or dry cells, $1 / n$ is the empirical constant that provides an indication of the intensity of adsorption. The adsorption isotherms were obtained by plotting $\log C_{b}$ as a function of $\log C_{t}$.

\section{Results and Discussion}

Biosorption of heavy metals $\mathrm{Cd}(\mathrm{II}), \mathrm{Ag}(\mathrm{I}), \mathrm{Cr}(\mathrm{III}), \mathrm{Cr}(\mathrm{VI})$
$\mathrm{Au}(\mathrm{III})$ by the blue-green algae Spirulina platensis, actinomycetes belonging to Arthrobacter genera-Arthrobacter globiformis 151B and Arthrobacter oxydans 61B, few new bacterial strains of actinomycetes Streptomyces spp. $19 \mathrm{H}$ were studied at different conditions. In particular, the impact of the following parameters on biosorption was studied for the microorganism-metal interaction: $\mathrm{pH}$ (for $\mathrm{Ag}, \mathrm{Cd}, \mathrm{Au}$ ), living and non-living cells (for $\mathrm{Cr}$ ), heavy metal valence (for $\mathrm{Cr}$ ), homogenized and non-homogenized cells (for $\mathrm{Au}$ ), $\mathrm{Zn}$ (II) ions (on $\mathrm{Cr}(\mathrm{VI})$ Arthrobacter species). Figure 1 shows the biosorption isotherms as an example of $\mathrm{Cd}(\mathrm{II})$-Spirulina platensis interaction at different $\mathrm{pH}$ values. For $\mathrm{A}, \mathrm{B}$ and $\mathrm{C}$ cases, cyanobacteria were dissolved in phosphate buffer $(\mathrm{pH}$ 7.0), in nutrient medium ( $\mathrm{pH} 8.6)$ and in water $(\mathrm{pH} 5.5)$, respectively. The results of equilibrium batch sorption experiments resulted are shown by the dots in the biosorption isotherms, which were approximated by the Freundlich model. Each dot is the average of three independent values, and the standard deviation is less than $13 \%$ of the average value. In all cases, the correlation between the experimental and the theoretical data is obvious ( $R$ is more than 0.9 ). By means of Freundlich isotherms the biosorption constant $(K)$ and the capacity $(n)$ were determined for Cd(II) Spirulina platensis. Similar data were obtained for $\mathrm{Ag}(\mathrm{I})$ and $\mathrm{Au}(\mathrm{III})$ Spirulina platensis. The results of equilibrium sorption experiments are listed in Table 1.

As seen from Table 1, Spirulina platensis showed different binding patterns for $\mathrm{Cd}(\mathrm{II}), \mathrm{Ag}(\mathrm{I})$ and $\mathrm{Au}(\mathrm{III})$. In particular, the biosorption parameters changed with changing $\mathrm{pH}$ value. Namely, in the case of high $\mathrm{pH}$ value ( $\mathrm{pH}$ 8.6), the biosorption constant of $\mathrm{Ag}(\mathrm{I})$ Spirulina platensis $K=9.4 \times 10^{-4}$ exceeded the biosorption con-

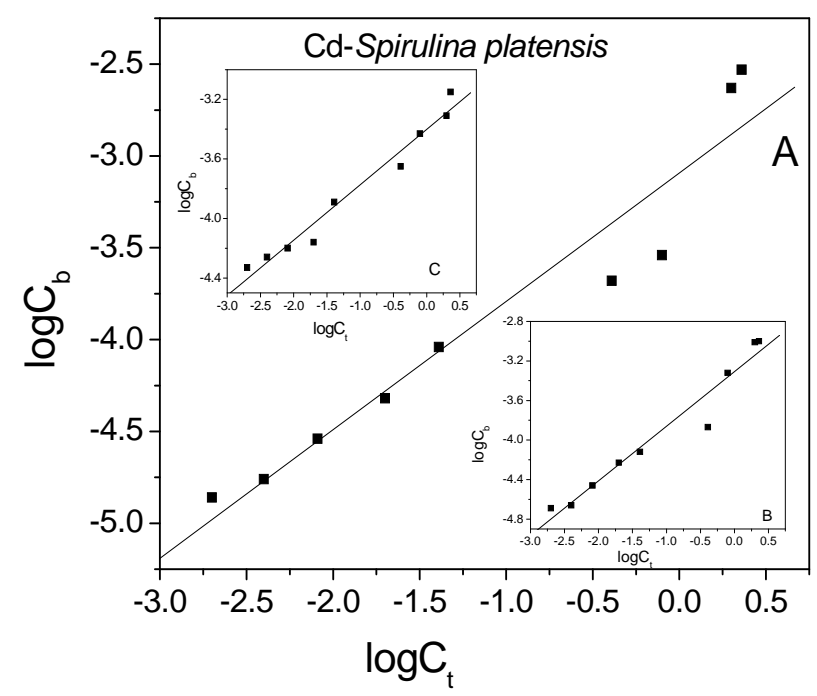

Figure 1. Biosorption isotherms for Cd(II) Spirulina platensis at different $\mathrm{pH}$ obtained by using the fitted Freundlich model. 
Table 1. Biosorption constants for $\mathrm{Cd}$, Au and Ag biosorption by Spirulina platensis.

\begin{tabular}{llccc}
\hline & & $\begin{array}{c}\text { Spirulina platensis dissolved in the } \\
\text { medium } \mathrm{pH} 8.6\end{array}$ & $\begin{array}{c}\text { Spirulina platensis dissolved in the } \\
\text { phosphate buffer } \mathrm{pH} 7.0\end{array}$ & $\begin{array}{c}\text { Spirulina platensis dissolved } \\
\text { in water } \mathrm{pH} 5.5\end{array}$ \\
\hline Biosorption constant $K$ & $\mathrm{Ag}$ & $9.4 \times 10^{-4}$ & $13.0 \times 10^{-4}$ & $2.9 \times 10^{-4}$ \\
& $\mathrm{Cd}$ & $5.1 \times 10^{-4}$ & $8.3 \times 10^{-4}$ & $3.6 \times 10^{-4}$ \\
& $\mathrm{Au}$ & $8.7 \times 10^{-4}$ & $2.07 \times 10^{-4}$ & $4.87 \times 10^{-4}$ \\
Biosorption capacity $n$ & $\mathrm{Ag}$ & 1.67 & 5.27 & 2.78 \\
& $\mathrm{Cd}$ & 1.82 & 1.45 & 2.7 \\
& $\mathrm{Au}$ & 1.58 & 1.39 & 0.93 \\
Correlation coefficient $R$ & $\mathrm{Ag}$ & 0.92 & 0.97 & 0.97 \\
& $\mathrm{Cd}$ & 0.98 & 0.96 & 0.97 \\
& $\mathrm{Au}$ & 0.96 & 0.97 & 0.98 \\
\hline
\end{tabular}

stant for $\mathrm{pH} 5.5\left(K=2.9 \times 10^{-4}\right)$, and the capacity differed by a factor of 1.5. The $\mathrm{pH}$ dependence was also obtained for $\mathrm{Cd}(\mathrm{II})$ and $\mathrm{Au}(\mathrm{III})$ Spirulina platensis. The absorption of $\mathrm{Cd}(\mathrm{II})$ and $\mathrm{Ag}(\mathrm{I})$ increased at $\mathrm{pH} 7.0$, while $\mathrm{Au}$ (III) had very low sorption at $\mathrm{pH}$ 7.0. Gold(III) was more effectively adsorbed by test algae at low $\mathrm{pH}$ value (pH 5.5) than $\mathrm{Cd}(\mathrm{II})$ and $\mathrm{Ag}(\mathrm{I})$. This can be explained by the fact that, as the $\mathrm{pH}$ value decreased, the surface charge on the algae cells became positive, and the interaction of $\mathrm{Au}(\mathrm{III})$ in anionic forms with the binding sites was primarily electrostatic. This would lead to electrostatic attractions between positively charged cations (Ag, $\mathrm{Cd}$ ) and negatively charged binding sites and hence to the rapid increase in binding efficiency in the range $\mathrm{pH}$ 5.5 to $\mathrm{pH}$ 7.0. The maximum uptake of cadmium and silver biosorption was observed at $\mathrm{pH}$ 7.0. On the other hand, the optimum biosorption for gold(III) was observed at $\mathrm{pH}$ 8.6. Hence we can assume that the effect of $\mathrm{pH}$ is related to different protonation of the functional groups present in the cell membrane. They are several chemical groups that attract metals in biomass: mainly carboxyls and sulphates in polysaccharides of marine algae. In [16] it was hypothesized that $\mathrm{Cd}, \mathrm{Cu}$ and $\mathrm{Co}$ biosorption by dead biomass of algae takes place through electrostatic interactions between the metal ions in solution and the cell walls of microbial cells.

In acidic conditions, the absorption capacity was found to be very low for gold ( $n=0.93)$, but high for $\mathrm{Cd}$ and Ag (2.7 and 2.8, respectively). For other $\mathrm{pH}$ values, the difference between the capacities is insignificant. The difference in the magnitude of capacity of metal ion binding may be related to the properties of the algae and the properties of the metal sorbents. Carboxylic, sulphydryl, phosphate and thiol groups differ in their affinity and specificity for metal binding.

Thus, the $\mathrm{pH}$ value exerted the most important effect on the biosorption of metal ions. Similar results were reported in [17], where it was revealed that the solution $\mathrm{pH}$ and ionic strength were very important factors in the metal biosorption and the biosorption capacity of $P$. aeruginosa AT18 for $\mathrm{Cr}(\mathrm{III}), \mathrm{Cu}(\mathrm{II}), \mathrm{Mn}(\mathrm{II})$ and $\mathrm{Zn}(\mathrm{II})$. In this case, the biosorption increased with the increasing $\mathrm{pH}$ value in the range $\mathrm{pH} 5.46$ - 7.72. The metal uptake capacity of Egyptian marine algae was studied using the species of green and brown algae, namely, Ulva lactuca L. and Sargassum latifolium (Turner) C. Agardh, respectively. The biosorption efficiency of $\mathrm{Cu}(\mathrm{II}), \mathrm{Co}(\mathrm{II}), \mathrm{Ni}(\mathrm{II})$, $\mathrm{Cd}(\mathrm{II}), \mathrm{Hg}(\mathrm{II}), \mathrm{Ag}(\mathrm{I})$ and $\mathrm{Pb}(\mathrm{II})$ ions seems to depend on the type of algae used as well as on the conditions [18]. In work [19], the potential of green marine macroalgae for removal of $\mathrm{Cd}, \mathrm{Hg}$ and $\mathrm{Pb}$ from aqueous solutions was assessed. The results obtained in that study indicated the highest absorption ability of Chaetomorpha sp. for $\mathrm{Cd}$ and $\mathrm{Pb}$.

The metal-removing ability of living or dry cells of bacteria (Arthrobacter globiformis and Arthrobacter oxidas) was studied as a function of metal concentration. The linearized absorption isotherms of $\mathrm{Cr}$ ions in anion and cation forms for two kinds of Arthrobacter were obtained by fitting the experimental dots. The Freundlich parameters evaluated from the isotherms with the correlation coefficients are given in Table 2 . The data in Table 2 show significant difference between the binding constants for $\mathrm{Cr}(\mathrm{VI})$-Arthrobacter oxidas and $\mathrm{Cr}(\mathrm{VI})$ Arthrobacter globiformis. The decrease in bioavailability was observed experimentally for $\mathrm{Cr}(\mathrm{VI})$-Arthrobacter globiformis as compared with Arthrobacter oxidas. It was shown that the carboxyl groups were the main binding sites in the cell wall of gram-positive bacteria [20]. Such bond formation could be accompanied by the displacement of protons and is dependent in part on the extent of protonation, which is determined by the $\mathrm{pH}$ value [21].

Our results indicated that $\mathrm{Cr}(\mathrm{VI})$ sorption depended on the species of Arthrobacter bacteria. The difference between Arthrobacter species in metal ion binding may be related to the properties of metal sorbates and the properties of bacteria (functional groups, structure and surface 
Table 2. Biosorption characteristics for Cr(VI) and Cr(III) Arthrobater oxidas and Cr(VI) and Cr(III) Arthrobacter globiformis.

\begin{tabular}{|c|c|c|c|c|c|c|}
\hline & $\operatorname{Cr}(\mathrm{VI})$ & & & $\mathrm{Cr}(\mathrm{III})$ & & \\
\hline Biosorption characteristics $(K, n)$ & $K \times 10^{-4}$ & $n$ & $R$ & $K \times 10^{-4}$ & $n$ & $R$ \\
\hline Arthrobater oxidas (dry cells) & 4.6 & 1.25 & 0.98 & 26.0 & 1.37 & 0.98 \\
\hline Arthrobacter globiformis (dry cells) & 3.4 & 1.35 & 0.96 & 20.2 & 1.23 & 0.98 \\
\hline Arthrobater oxidas (living cells) & 1.0 & 1.25 & 0.94 & - & - & - \\
\hline Arthrobater oxidas $+\mathrm{Zn}(\mathrm{II})$ & 6.6 & 1.08 & 0.98 & - & - & - \\
\hline Arthrobacter globiformis $+\mathrm{Zn}(\mathrm{II})$ & 8.1 & 1.19 & 0.96 & - & - & - \\
\hline
\end{tabular}

area, varying in the species). Functional groups [22], such as amino, carboxylic, suphydryl, phosphate and thiol groups, differ in their affinity and specifity for metal binding. The $n$ values which reflect the intensity of sorption represent the same trend, but, as obvious from Table 2, for both Arthrobacter species the $n$ values differ insignificantly, and their sorption intensity indicators are small (1.08 - 1.47).

Comparative Freundlich biosorption characteristics of the $\mathrm{Cr}(\mathrm{VI})$-Arthrobacter species in living and dry cells (Table 2) show that the $n$ values are the same in both cases. The dry cells have higher biosorption constants for both species $(\mathrm{K})\left(4.6 \times 10^{-4}, 3.4 \times 10^{-4}\right)$ than the living ones $\left(1.0 \times 10^{-4}, 1.36 \times 10^{-4}\right)$. This may confirm the hypothesis that the metal sorption by these bacteria is independent of the metabolic state of the organism [23].

The comparison of $\mathrm{Cr}(\mathrm{VI})$ - and $\mathrm{Cr}(\mathrm{III})$-Arthrobacter species interactions (Table 2) showed that $\mathrm{Cr}$ (III) was absorbed more effectively than $\mathrm{Cr}(\mathrm{VI})$ by both bacteria. The absorption capacity is the same for both chromiumArthrobacter systems. The biosorption constants for $\mathrm{Cr}(\mathrm{III})$ are higher than for $\mathrm{Cr}(\mathrm{VI})$ by a factor of $5.65-5.88$ for both species. $\mathrm{Cr}(\mathrm{VI})$ is one of the most stable oxidation states, the others being chromium(II) and chromium(III). $\mathrm{Cr}$ (VI) can be reduced to $\mathrm{Cr}$ (III) by the biomass through two different mechanisms [24]. The "uptake-reduction" model for Chromium(VI) carcinogenicity is that tetrahedral chromate is actively transported across the cell membrane. Chromium(III) is not actively transported across the cell membrane to lack of transport mechanisms for these octahedral complexes. Thus, $\mathrm{Cr}(\mathrm{VI})$ may be absorbed by bacteria at a much lower degree than $\mathrm{Cr}$ (III). The above mentioned is in good agreement with literature data according to which there is a significant difference in the efficiency of absorption in each species of microorganisms, since the sorption depends on the nature and the composition of the cell wall [25]. On the other hand, gram-positive bacteria have greater sorptive capacity due to their thicker layer of peptidoglycan, which contains numerous sorptive sites [26].

It is seen from Table 2 that the bioavailability in- creased in the presence of $\mathrm{Zn}$ ions in both cases (for $\mathrm{Cr}(\mathrm{VI})$-Arthrobacter globiformis and for Cr(VI)-Arthrobacter oxidas). But for Cr(VI)-Arthrobacter globiformis this increase was more significant. The presence of other cations increased the uptake of the target cations by bacteria. Such an effect of the other cation ( $\mathrm{Zn}(\mathrm{II})$ ) suggests that at least ion exchange is one of the mechanisms responsible for metal uptake by such Arthrobacter species. This has implications for the selection of Arthrobacter species for indrustrial applications. Biosorption is often accompanied by a slower metal binding process in which the additional metal ion is bound, often irreversibly. This slow phase of metal uptake can be due to a number of mechanisms, including covalent bonding, crystallization on the cell surface or, most often, diffusion into the cell interior and binding to proteins and other intercellular sites [27].

In Figure 2 are shown biosorption isotherms for goldStreptomyces spp. $19 \mathrm{H}$ cells (1-homogenized cells and 2-partially homogenized cells). By means of Freundlich isotherms the biosorption constants $(K)$ and the capacity (n) were determined for gold-Streptomyces spp. $19 \mathrm{H}$ cells. They are equal to: $K=8.2 \times 10^{-4}, n=1.64$ (gold-

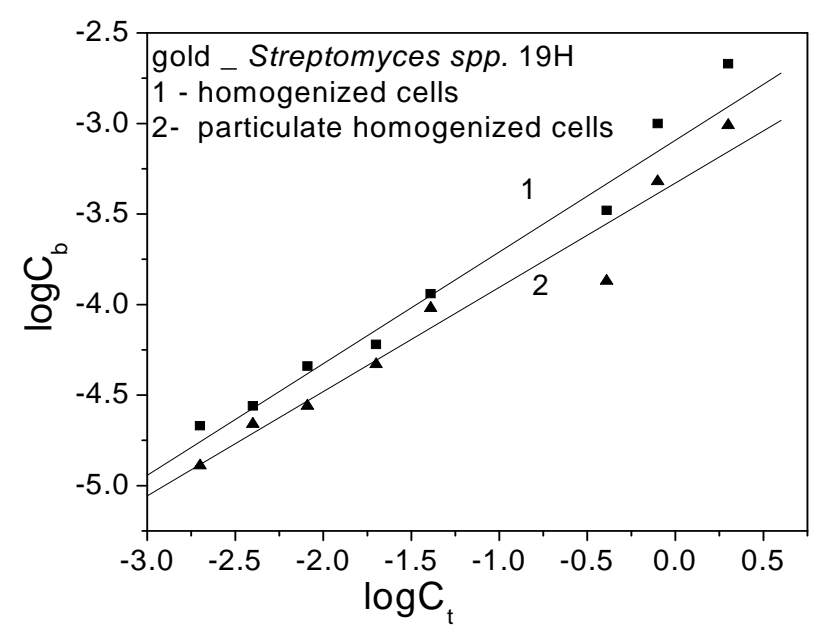

Figure 2. Linearized Freundlich absorption isotherms for Au(III) Streptomyces spp. $19 \mathrm{H}$ cells. 
Streptomyces spp. 19H-homogenized cells) and $K=4.8$ $\times 10^{-4}, n=1.75$ (gold-Streptomyces spp. 19H-partially homogenized cells). It is clear that the biosorption constant for homogenized cells is greater than for particulate homogenized cells, and in both cases the sorptive capacity is greater.

Thus, different species of bacteria displayed different sorptive relationships. The obtained biosorption data are in good agreement with the literature data according to which biological ligands are generally polyfunctional and polyelectrolytic, with an average $\mathrm{pK}$ value within 4.0 6.0 [28].

\section{Conclusion}

The biosorption of four different bacteria: cyanobacteria (blue-green algae) Spirulina platensis, actinomycetes belonging to Arthrobacter genera-Arthrobacter globiformis 151B and Arthrobacter oxydans 61B, few new bacterial strains of actinomycetes Streptomyces spp. 19H was evaluated in the biosorption of cadmium, chromium, silver and gold from aqueous solutions. The comparison of these results with similar studies confirmed that our selected organisms were efficient in absorption of heavy metals. The efficiency of biosorption of $\mathrm{Cr}(\mathrm{III}), \mathrm{Cr}(\mathrm{VI})$, $\mathrm{Cd}(\mathrm{II}), \mathrm{Au}(\mathrm{III})$ and $\mathrm{Ag}(\mathrm{I})$ ions likely depends on the type of the bacteria used as well as on the conditions under which the uptake processes proceeded.

\section{REFERENCES}

[1] M. A. Qureshi, J. D. Garlich and M. T. Kidd, "Dietary Spirulina platensis Enhances Humoral and Cell-Mediated Immune Functions in Chickens," Immunopharmacology and Immunotoxicology, Vol. 18, No. 3, 1996, pp. 465-476. doi:10.3109/08923979609052748

[2] M. Borisev, S. Pajevic, N. Nikolic, A. Pilipovic, B. Krstic and $\mathrm{S}$. Orlovic, "Phytoextraction of $\mathrm{Cd}, \mathrm{Ni}$ and $\mathrm{Pb}$ Using Four Willow Clones (Salix spp.)," Polish Journal of Environmental Studies, Vol. 18, No. 4, 2009, p. 553.

[3] S. K. Ali and A. M. Saleh, "Spirulina-An Overview," International Journal of Pharmacy and Pharmaceutical Sciences, Vol. 4, No 3, 2012, pp. 9-15.

[4] S. K. Soni, K. Agrawal, S. K. Srivastava, S. Gupta and C. K. Pankaj, "Growth Performance and Biochemical Analysis of Spirulina platensis under Different Culture Conditions," Journal of Algal Biomass Utilization, Vol. 3, No. 1, 2012, pp. 55-58.

[5] N. Albert, R. Wague, M. Mbaïlao and N. Fabienne, "Changes in the Physico-Chemical Properties of Spirulina platensis from Three Production Sites in Chad," Journal of Animal \& Plant Sciences, Vol. 13, No. 3, 2012, pp. 1811-1822.

[6] A. Ahmad, R. Ghufran and Z. A. Wahid, "Cd, As, Cu, and Zn Transfer through Dry to Rehydrated Biomass of Spirulina platensis from Wastewater," Polish Journal of Environmental Studies, Vol. 19, No. 5, 2010, pp. 887-
893.

[7] M. Ghaedi, E. Asadpour and A. Vafaie, "Sensitized Spectrophotometric Determination of $\mathrm{Cr}(\mathrm{III})$ Ion for Speciation of Chromium Ion in Surfactant Media Using Benzoin Oxime," Spectrochimica Acta, Part A, Vol. 63, No. 1, 2006, pp. 182-188. doi:10.1016/j.saa.2005.04.049

[8] J. P. Guggenbichler, M. Boswald, S. Lugauer and T. Krall, "A New Technology of Microdispersed Silver in Polyurethane Induces Antimicrobial Activity in Central Venous Catheters," Infection, Vol. 27, No. 1, 1999, pp. 1623. doi:10.1007/BF02561612

[9] M. F. Lengka, B. Ravel, M. E. Fleet, G. Wanger, R. A. Gordon and G. Southam, "Mechanisms of Gold Bioaccumulation by Filamentous Cyanobacteria from Gold(III)Chloride Complex," Environmental Science \& Technology, Vol. 40, No. 20, 2006, pp. 6304-6309. doi:10.1021/es061040r

[10] V. Karamuchka and G. M. Gadd, "Interaction of Saccharomyces cerevisiae with Gold: Toxicity and Accumulation," Biometals, Vol. 12, No. 4, 1999, pp. 289-294. doi:10.1023/A:1009210101628

[11] I. Savvaidis, V. I. Karamushka, H. Lee and J. T. Trevors, "Microorganism-Gold Interactions," Biometals, Vol. 11, No. 1, 1998, pp. 69-78. doi:10.1023/B:BIOM.0000030925.56070.56

[12] N. Y. Tsibakhashvili, L. M. Mosulishvili, T. L. Kalabegishvili, D. T. Pataraya, M. A. Gurielidze, G. S. Nadareishvili and H.-Y. Holman, "Chromate-Resistant and Reducing Microorganisms in Georgia Basalts: Their Distribution and Characterization," Fresenius Environmental Bulletin, Vol. 11, No. 7, 2002, pp. 352-361.

[13] L. Mosulishvili, A. Belokobilsky, E. Gelagutashvili, A. Rcheulishvili and N. Tsibakhashvili, "The Study of the Mechanism of Cadmium Accumulation during the Cultivation of Spirulina Platensis," Proceedings of the Georgian Academy of Sciences Biological Series, Vol. 23, No. 1-6, 1997, pp. 105-113.

[14] N. Y. Tsibakhashvili, E. I. Kirkesali, D. T. Pataraya, M. A. Gurielidze, T. L. Kalabegishvili, D. N. Gvarjaladze, G. T. Tsertsvadze, M. V. Frontasyeva, I. I. Zinicovskaia, M. S. Wakstein, S. N. Khakhanov, N. V. Shvindina and V. Y. Shklover, "Microbial Synthesis of Silver Nanoparticles by Streptomyces glaucus and Spirulina platensis," International Journal Advanced Science Letters, Vol. 4, No. 11-12, 2011, pp. 1-10.

[15] H. Freundlich, “Adsorption in Solutions," Journal of Physical Chemistry, Vol. 57, 1906, pp. 384-410.

[16] N. Kuyucak and B. Volesky, "Biosorbents for Recovery of Metals from Industrial Solutions," Biotechnology Letters, Vol. 10, No. 2, 1988, pp. 137-142. doi:10.1007/BF01024641

[17] R. M. Perez Silva, A. A. Rodriguez, J. G. Montes De Oca and D. C. Moreno, "Biosorption of Chromium, Copper, Manganese and Zinc by Pseudomonas aeruginosa AT18 Isolated from a Site Contaminated with Petroleum," Bioresource Technology, Vol. 100, No. 4, 2009, pp. 15331538. doi:10.1016/j.biortech.2008.06.057

[18] A. H. Elrefaii, L. A. Sallam and A. A. Hamdy, "Optimization of Some Heavy Metals Biosorption by Representa- 
tive Egyptian Marine Algae," Journal of Phycology, Vol. 48, No. 2, 2012, pp. 471-474.

doi:10.1111/j.1529-8817.2012.01114.x

[19] J. I. Nirmal Kumar, C. Oommen and R. N. Kumar, "Biosorption of Heavy Metals from Aqueous Solution by Green Marine Macroalgae from Okha Port, Gulf of Kutch, India," American-Eurasian Journal of Agricultural \& Environmental Sciences, Vol. 6, No. 3, 2009, pp. 317-323.

[20] M. G. Gadd and C. White, "Microbial Treatment of Metal Pollution-A Working Biotechnology," Trends in Biotechnology, Vol. 11, No. 8, 1993, pp. 353-359. doi:10.1016/0167-7799(93)90158-6

[21] T. R. Muraleedharan, L. Iyengar and C. Venkobacher, "Biosorption: An Attractive Alternative for Metal Removal and Recovery," Current Science, Vol. 61, 1991, pp. 379-385.

[22] Y. P. Tin, F. Lawson and I. G. Prince, "Uptake Cadmium and Zinc by the Chlorella vudguris: Part II. Multi-Ion Situation," Biotechnology and Bioengineering, Vol. 37, No. 5, 1991, pp. 445-455. doi:10.1002/bit.260370506

[23] D. L. Parker, C. RaiL, N. Mallick, P. K. Rai and H. D. Kumar, "Effects of Cellular Metabolism and Viability on Metal Ion Accumulation by Cultured Biomass from a
Bloom of Microcytis aeruginosa," Applied and Environmental Microbiology, Vol. 64, 1998, pp. 1545-1547.

[24] D. Park, Y.-S., Yun and J. M. Park, "Studies on Hexavalent Chromium Biosorption by Chemically-Treated Biomass of Ecklonia sp.," Chemosphere, Vol. 60, No. 10, 2005, pp. 1356-1364.

doi:10.1016/j.chemosphere.2005.02.020

[25] O. Hammouda, A. Gaber and N. Raouf-Abdel, "Microalgae and Wastewater Treatment," Ecotoxicology and Environmental Safety, Vol. 31, No. 3, 1995, pp. 205-210. doi:10.1006/eesa.1995.1064

[26] E. D. Van Hullebusch, M. H. Zandvoort and P. N. L. Lens, "Metal Immobilization by Biofilms. Mechanisms and Analytical Tools," Reviews in Environmental Science and Bio/Technology, Vol. 2, 2003, pp. 9-33.

[27] H. B. Xue and L. Sigg, "The Binding of Heavy Metals to Algae Surfaces," Water Research, Vol. 22, No. 7, 1990, pp. 917-926. doi:10.1016/0043-1354(88)90029-2

[28] K. J. Wilkinson and J. Buffle, "Physicochemical Kinetics and Transport at Chemical-Biological Interphases," John Wiley, Chichester, 2004, p. 445. doi:10.1002/0470094044.ch10 